\title{
Growth performance, nutrient digestibility, metabolizable energy, and intestinal morphology of growing turkeys fed diet supplemented with arginine
}

by Oso, A.O., Williams, G.A., Oluwatosin, O.O., Bamgbose, A.O., Adebayo, A.O., Olowofeso, V., Pirgozliev, V., Adegbenjo, A.A., Osho, S.O., Alabi, J.O., Li, F., Liu, H., Yao, K. and Xin, W.

Copyright, Publisher and Additional Information: This is the author accepted manuscript. The final published version (version of record) is available online via Elsevier Please refer to any applicable terms of use of the publisher.

DOI: http://dx.doi.org/10.1016/j.livsci.2017.01.018

Harper Adams

University 
1 Growth performance, nutrient digestibility, metabolizable energy, and intestinal morphology of growing turkeys fed diet supplemented with arginine

3 A.O. Oso ${ }^{\text {a, b, * }}$, G.A. Williams ${ }^{\text {b }}$, O.O. Oluwatosin ${ }^{\text {a, b }}$, A.M. Bamgbose ${ }^{\text {a, b}}$, A.O. Adebayo

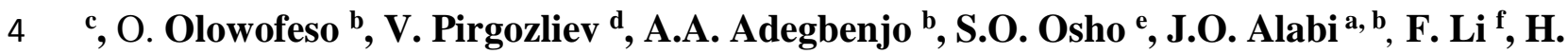

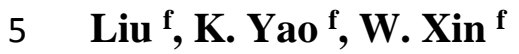

6

$7 \quad{ }^{a}$ World Bank Centre of Excellence in Agricultural Development and Sustainable

8 Environment, Federal University of Agriculture, Abeokuta, PMB 2240, Nigeria.

$9{ }^{b}$ College of Animal Science and Livestock Production, Federal University of Agriculture, Abeokuta, PMB 2240, Nigeria.

${ }^{c}$ College of Veterinary Medicine, Federal University of Agriculture, Abeokuta, PMB 2240, Nigeria.

${ }^{d}$ Department of Animal Production, Welfare and Veterinary Sciences, Harper Adams

University, Newport TF 10 8NB, United Kingdom.

${ }^{d}$ Department of Animal Sciences, Purdue University, West Lafayette, IN 47907-2054, United

States.

${ }^{f}$ Key Laboratory for Agro-Ecological Processes of Subtropical Region, Institute of

Subtropical Agriculture, The Chinese Academy of Sciences and Hunan Provincial

Engineering Research Center for Healthy Livestock and Poultry Production, Changsha, 410125, China. 
A 8-wk feeding experiment was conducted to investigate the effect of dietary supplementation with Arg on growth performance, nutrient digestibility, metabolizable energy, and intestinal morphology of growing turkeys. A total of one hundred and eighty 56d-old male grower turkeys were weighed individually and randomly assigned to 1 of 3 dietary treatments with 6 replicate pens and 10 turkeys per pen in a completely randomized design. Dietary treatments consisted of basal diets supplemented with $0,0.5$, and $1.0 \mathrm{~g} \mathrm{Arg} / \mathrm{kg}$. Growth response was measured during the grower (d 56 to 84 ) and finisher (d 84 to 112 ) phases, while nutrient digestibility, metabolizable energy, and intestinal morphology were measured at d 84 and 112. Arginine supplementation had no effect on growth response during the grower phase. During the finisher phase, feed conversion ratio decreased initially as Arg supplementation increased from 0 to $0.5 \mathrm{~g} / \mathrm{kg}$, but it increased with the $1.0 \mathrm{~g} \mathrm{Arg} / \mathrm{kg}$ (quadratic, $P=0.028$ ). At d 84, grower turkeys fed diets supplemented with $1.0 \mathrm{~g} \mathrm{Arg} / \mathrm{kg}$ had greater (linear, $P<0.001$ ) apparent dry matter, crude protein, and ether extract digestibility. At d 84, greatest apparent metabolizable energy, nitrogen corrected apparent metabolizable energy, and true metabolizable energy values were obtained with grower turkeys fed diet supplemented with $0.5 \mathrm{~g} \mathrm{Arg} / \mathrm{kg}$ (quadratic, $P<0.001$ ). At d 84, duodenum, and ileum villus height in grower turkeys increased linearly, and quadratically $(P<0.001)$ with increasing Arg supplementation. Dietary supplementation with Arg reduced the apical widths in duodenum (quadratic, $\mathrm{P}=0.042$ ), and ileum villus height (linear, $P=0.022$; quadratic, $P=0.042$ ) of finisher turkeys increased, while duodenum apical widths reduced (quadratic, $P=0.033$ ) with increasing Arg supplementation. In conclusion, Arg supplementation showed a linear 
in grower, and finisher turkeys as indicated by increased intestinal villus height at $d 84$, and 112. Furthermore, dietary supplementation with $0.5 \mathrm{~g}$ Arg/kg promoted a quadratic improvement in feed conversion ratio of finisher turkeys, and metabolizable energy values of grower turkeys at $\mathrm{d} 84$.

Keywords: Growing turkeys, Gut morphology, Arginine, Metabolizable energy

\section{Introduction}

Arginine is known as one of the most versatile amino acids in body cells and plays a vital role as a substrate for protein synthesis, it acts as an intermediate in the hepatic urea cycle, as well as precursor for the synthesis of various important metabolic molecules, including nitric oxide (NO), polyamines, and creatinine (Kim et al., 2007; Wu and Morris, 1998). Arginine increased the release of growth hormone and insulin-like growth factor (IGFI) in the blood (Newsholme et al., 2005), improved muscle performance, facilitated glucose uptake into the muscle cells (Stevens et al., 2000; Tan et al., 2009), regulated expression of fat-metabolic genes (Tan et al., 2011), improved the jejunal activities for carbohydrate, and protein digestion (Uni and Ferket, 2003).

Arginine increased protein synthesis, improved growth of poultry birds (Kidd et al., 2001), and attenuated whole body growth in growing pigs fed mold-contaminated diet (Yin et al., 2014). Arginine supplementation also improved daily weight gain of milk-fed piglets (Kim and Wu, 2004). Dietary supplementation with Arg activated intestinal innate immunity of mice (Ren et al., 2014a) and ameliorated intestinal abnormalities in growing pigs (Yin et al., 2014). Increased final body weight gain of broilers (Munir et al., 2009) and piglets (Yao et al., 2011) have been reported following dietary supplementation with Arg. Kidd et al. (2001) also reported that increasing dietary Arg from 100 to $120 \%$ of NRC (1994) 
recommendation resulted in increased body weight gain of broilers. Ren et al. (2014b) suggested that Arg supplementation could be a potential therapy for intestinal inflammatory disease.

Mammals are able to synthesize their own Arg in order to meet their nutritional requirements. However, birds appear unable to synthesize Arg via the urea cycle due to lack of carbamoyl phosphate synthetase I in mitochondria (Lewis, 1996). Therefore, chickens depend completely on exogenous arginine to meet their needs for protein synthesis and other functions (Tamir and Ratner, 1963). In poultry birds fed practical corn-soybean meal based diets, Arg was regarded as the fifth limiting amino acid, after Met, Lys, Thr, and Val (Vieira and Berres 2007). Hence, adequate dietary levels of these amino acids are needed to support optimum growth and carcass yield of fast-growing commercial birds like turkeys.

Genetic selection of modern-day poultry with a view to improve growth, body weight gain, feed efficiency, and breast muscle weight within a short period (Burt, 2002) had resulted in increased susceptibility of poultry to various stressors (Lin et al., 2006). Stress removal has become one of the most important challenges in poultry production, especially in tropical, and subtropical areas. Mujahid (2007) reported that alleviating stressors through dietary manipulations are considered practical solution in enhancing poultry performance reared under tropical condition. Dietary supplementation with Arg has been reported to alleviate stressors in birds (Attia et al., 2011). Previous studies showed that chickens required more Arg than NRC (1994) recommendations under stress conditions (Brake et al., 1998).

With the goal of modern-day turkey production which, seeks to attain highest weight gain and meat yield over a short period, it will be worthwhile to investigate the effect of supplemental Arg in turkeys raised under tropical condition. The current study, therefore, investigated the effect of diet supplemented with Arg on growth performance, nutrient digestibility, metabolizable energy, and intestinal morphology of growing turkeys. 


\section{Materials and Methods}

\subsection{Management of turkeys}

This research work was conducted at the turkey unit of the Teaching and Research

Farms, University of Agriculture, Abeokuta, Nigeria during the late dry season. Experimental procedures were in accordance with the guidelines of the Animal Care Committee of the Federal University of Agriculture, Abeokuta Nigeria. A total of 200 one-day-old, male turkey poults obtained from a commercial hatchery (British United Turkeys; Obasanjo Farms Ltd, Ibadan, Nigeria) were reared together under a deep litter housing system for a 56-d preexperimental period. Dried wood shavings were used as litter material. The pre-experimental period lasted for the pre-starter ( $\mathrm{d} 0$ to 28 ) and starter (d 28 to 56) phases of the turkeys.

Brooding of turkeys was done for 0 to $28 \mathrm{~d}$ of age, while normal ambient temperature prevailed after the brooding period. Turkeys were fed with commercial maize-soybean meal based pre-starter (metabolizable energy $(\mathrm{ME})=11.79 \mathrm{MJ} / \mathrm{kg}$, crude protein $(\mathrm{CP})=278 \mathrm{~g} / \mathrm{kg}$, Met $=5.1 \mathrm{~g} / \mathrm{kg}$, and Lys $=16 \mathrm{~g} / \mathrm{kg})$ and starter diets $(\mathrm{ME}=12.13 \mathrm{MJ} / \mathrm{kg}, \mathrm{CP}=259 \mathrm{~g} / \mathrm{kg}, \mathrm{Met}$ $=4.6 \mathrm{~g} / \mathrm{kg}$, and Lys $=15 \mathrm{~g} / \mathrm{kg}$ ), which met the NRC (1994) nutritional requirements of the various age groups. During the pre-experimental period, feed and clean water were supplied ad libitum, while no mortality occurred. After the 56-d pre-experimental period, the feeding study was initiated, which lasted for 8 wk.

\subsection{Dietary treatments}

At d 56, 180 male turkeys of similar weights were selected, weighed individually, and allotted to 1 of 3 treatments with 6 pens (dimension, $2.5 \times 1.8 \mathrm{~m}$ ) per treatment, and 10 turkeys per pen in a completely randomized design. A total of 18 similar floor pens were used in this study. The pens were furnished with wood shavings as beddings. A maizesoybean meal diet (basal diet), which met the NRC (1994) nutritional requirement was 
formulated for grower (d 56 to 84), and finisher (d 84 to 112) phases of turkeys (Table 1).

Two additional experimental diets were subsequently formulated for the grower and finisher phases by supplementing the basal diet with 0.5 and $1 \mathrm{~g} \mathrm{Arg} / \mathrm{kg}$ (Shanghai TECH Chemical Industry, Shanghai, China). Turkeys had ad libitum access to feed and water.

\subsection{Growth performance}

The bodyweight of the birds per pen was measured on a weekly basis, while the gain in weight was computed. Daily feed intake was also measured as the difference between the feed offered and leftovers, while feed conversion ratio was also computed. A record of mortality was kept as it occurred.

\subsection{Nutrient digestibility and metabolizable energy}

Metabolism trial was conducted at d 84 and 112 of the study. Briefly, a turkey per replicate was randomly selected and housed separately in appropriate metabolism cages fitted with individual feed troughs and facility for separate excreta collection. The turkeys were acclimatized for $2 \mathrm{~d}$ prior to the commencement of $4 \mathrm{~d}$ collection period. Excreta collected per turkey per day was oven dried $\left(60^{\circ} \mathrm{C}\right)$ and used for analysis. Proximate composition of feed and dried excreta samples were analyzed for dry matter (Method 934.01), crude fibre (Method 978.01), ether extract (Method 920.39), ash (Method 942.05), and crude protein (N $\times$ 6.25; Method 990.03) using standard methods of AOAC (2000). Amino acids contents of the diets were determined (Harper Adams University Laboratory, Newport, UK) using HPLC (SSNIFF Spezialdiäten GmbH, Soest, Germany) and following standard methods (European Commission, 1998).

At the expiration of metabolic trial, turkeys were starved of diets, given unrestricted access to clean water for $24 \mathrm{~h}$ during which the excreta voided were discarded. After the expiration of $24 \mathrm{~h}$ starvation, each turkey was dosed with $50 \mathrm{~mL}$ of warm glucose solution to 
reduce stress and deprived of feed for another $24 \mathrm{~h}$ making a total of $48 \mathrm{~h}$ starvation period.

Total excreta collection per turkey during the last ( $24 \mathrm{~h})$ phase of feed starvation was used for the estimation of endogenous losses. Gross energy of excreta samples (from fed and starved turkeys) was estimated using the adiabatic bomb calorimeter (Model 1261; Parr Instrument Co., Moline, IL, US). The apparent metabolizable energy (AME), nitrogen corrected AME (AMEn), true metabolizable energy (TME), and nitrogen corrected TME (TMEn) were computed using the equations as described by Sibbald (1989).

\subsection{Intestinal morphology}

At d 84 and 112, a turkey per replicate was randomly selected, slaughtered, carcass opened, and the entire gastrointestinal tract excised. Samples were taken from the mid-region of the intestinal segments; duodenum (from gizzard outlet to the end of the pancreatic loop), jejunum (from the pancreatic loop to Meckel's diverticulum), and ileum (from Meckel's diverticulum to the cecal junction). The gut samples were washed with $0.1 \mathrm{M}$ phosphate buffered saline ( $\mathrm{pH} 7.4$ ), fixed in Bouin's solution for $6 \mathrm{~h}$, and dehydrated in a graded ethanol (xylene) series. Each segment was embedded in paraffin wax using standard technique. Intestinal histology was measured according to Hampson (1986). Villus height and crypt depth was determined by a Nikon Phase Contrast Microscope Integrated Digital Imaging Analyses (Nikon Tec, Shinagawa, Tokyo, Japan). The villi length was measured from the tip to the villi base, and the crypt depth was measured from the base of the villi to the base of the crypt. The villus widths were measured at the basal and apical parts to obtain the basal, and apical width, respectively.

\subsection{Statistical Analysis}

Data obtained from this study was subjected to one-way analysis of variance in a completely randomized design. The pen was used as the experimental units for statistical 
analysis. The data were statistically analyzed using the ANOVA procedure of SAS (1999).

Orthogonal polynomials were used to assess the linear and quadratic effects of varying supplemental levels of Arg.

\section{Results}

\subsection{Growth performance}

The growth performance of growing turkeys fed the diets supplemented with Arg is as shown in Table 2. At the grower phase, Arg supplementation had no effect on all growth parameters measured. During the finisher phase, feed intake initially reduced as Arg supplementation increased from 0 to $0.5 \mathrm{~g} / \mathrm{kg}$, but it increased with the $1.0 \mathrm{~g}$ Arg $/ \mathrm{kg}$ (linear, $P$ $=0.009 ;$ quadratic, $P<0.001)$. In a similar manner, feed conversion ratio of finisher turkeys decreased as Arg supplementation increased from 0 to $0.5 \mathrm{~g} / \mathrm{kg}$, but increased with the $1.0 \mathrm{~g}$ Arg/kg (quadratic, $P=0.028)$.

Effect of Arg supplementation on overall performance of turkeys measured at d 56 to 112 is shown in Table 2. Body weight of turkeys reduced quadratically as Arg supplementation increased from 0 to $0.5 \mathrm{~g} / \mathrm{kg}$, but showed a quadratic increase with the $1.0 \mathrm{~g}$ $\operatorname{Arg} / \mathrm{kg}(P=0.039)$. Feed intake initially reduced as Arg supplementation increased from 0 to $0.5 \mathrm{~g} / \mathrm{kg}$, but increased with the $1.0 \mathrm{~g} \mathrm{Arg} / \mathrm{kg}$ (linear, $P=0.022$; quadratic, $P=0.017$ ). Feed conversion ratio of turkeys measured at d 56 to 112 reduced as Arg supplementation increased from 0 to $0.5 \mathrm{~g} / \mathrm{kg}$, but increased with the $1.0 \mathrm{~g}$ Arg $/ \mathrm{kg}$ (linear, $P=0.015$ ).

\subsection{Nutrient digestibility}

Table 3 shows the dry matter and nutrient digestibility values of growing turkeys fed the diets supplemented with Arg. At d 84, grower turkeys fed diets supplemented with $1.0 \mathrm{~g}$ 
$\mathrm{Arg} / \mathrm{kg}$ had a greater (linear, $P<0.001$ ) dry matter, crude protein and ether extract, crude fibre, and ash digestibility values. Dry matter, crude protein, ether extract, and crude fibre digestibility of grower turkeys at d 84 increased linearly $(P<0.001)$ with increasing Arg supplementation.

In finisher turkeys measured at d 112, dry matter digestibility reduced (linear, $P=$ 0.014; quadratic, $P=0.030$ ), while ash digestibility increased (linearly and quadratic, $P<$ 0.001) with increasing Arg supplementation. Dietary supplementation with Arg had no effect on crude protein, ether extract, and crude fibre digestibility of finisher turkeys at d 112.

\subsection{Metabolizable energy values}

The metabolizable energy values of growing turkeys fed the diets supplemented with Arg is shown in Table 4. At d 84, AME, AMEn, and TME of grower turkeys increased quadratically as Arg supplementation increased from 0 to $0.5 \mathrm{~g} / \mathrm{kg}$, but reduced with the $1.0 \mathrm{~g}$ Arg $/ \mathrm{kg}(P<0.001)$. In a similar manner, TMEn increase as Arg supplementation increased from 0 to $0.5 \mathrm{~g} / \mathrm{kg}$, but reduced with the $1.0 \mathrm{~g} \mathrm{Arg} / \mathrm{kg}$ (quadratic, $P=0.021$ ). At d 112, Arg supplementation had no effect on AME, AMEn, TME, and TMEn values of finisher turkeys in this study.

\subsection{Intestinal morphology}

Table 5 shows the effect of Arg supplementation on intestinal morphology of grower turkeys at $\mathrm{d} 84$. The villus height increase (linear and quadratic, $P<0.001$ ), while apical width reduced (linear, $P=0.003$; quadratic, $P<0.001$ ) with increasing Arg supplementation in the duodenum of grower turkeys at $\mathrm{d} 84$. Basal width (quadratic, $P=0.047$ ) and crypt depth (linear, $P=0.043$; quadratic, $P<0.001$ ) reduced as Arg supplementation increased from 0 to $0.5 \mathrm{~g} / \mathrm{kg}$, but increase with the $1.0 \mathrm{~g}$ Arg/ $\mathrm{kg}$. 

(quadratic, $P<0.001)$. Apical width reduced linearly and quadratically $(P<0.001)$ with increasing Arg supplementation. Arginine supplementation had no effect on the jejunum basal width in grower turkeys at $\mathrm{d} 84$.

In the ileum of grower turkeys at $\mathrm{d} 84$, villus height increase linearly, and quadratically $(P<0.001)$ with increasing Arg supplementation. Dietary supplementation with Arg showed a linear and quadratic reduction (linear, $P=0.010$; quadratic, $P=0.004$ ) in apical widths of grower turkeys at $\mathrm{d} 84$. The basal width (linear, $P=0.004$; quadratic, $P=$ 0.021 ) and crypt depth (linear and quadratic, $P<0.001$ ) in the ileum also reduced with increasing Arg supplementation. reduced quadratically $(P=0.033)$ with increasing Arg supplementation. In the jejunum of finisher turkeys at d 112, villus height increase quadratically $(P=0.042)$ with increasing Arg supplementation. In the ileum of finisher turkeys at $\mathrm{d} 112$, villus height increase linearly and quadratically (linear, $P=0.022$; quadratic, $P=0.042$ ) with increasing Arg supplementation. Apical width, basal width, and crypt depth in the jejunum and ileum of finisher turkeys at d 112 were not affected by Arg supplementation. 
in this study agreed with previous literature. Veldkamp et al. (2000) reported that increasing dietary Arg supplementation had no effect on growth performance of 28 to $140 \mathrm{~d}$ male turkeys. Costa et al. (2001) investigated the effect of varying Arg/Lys ratios in diets of 22 to 42 d, male Ross broilers and reported no effect of Arg level on growth performance. Contrary opinion following dietary supplementation with Arg has been reported (Kwak et al., 1999). The absence of significant effect recorded in this study with respect to the growth performance of grower turkeys with increasing dietary Arg supplementation could be attributed to the similar Arg/Lys ratios of the experimental diets and the dosage of Arg supplemented. Increased supplemental levels of Arg above the concentration used in the current study (Labadan Jr et al., 2001) and increased Arg/Lys ratios (Mendes et al., 1997) were reported to improve feed conversion and production performance in broiler chickens. The differences between the findings obtained at the grower phase of the current study and previous literature could also be attributed to sex and species of birds used.

Improved feed conversion ratio obtained for finisher turkeys fed diet supplemented with $0.5 \mathrm{~g} \mathrm{Arg} / \mathrm{kg}$ when compared to turkeys fed diet supplemented with $1 \mathrm{~g}$ Arg/kg suggested a better utilization of dietary protein at the $0.50 \mathrm{~g} \mathrm{Arg} / \mathrm{kg}$. Takahashi et al. (1999) reported that dietary supplementation with Arg improved feed efficiency in male broiler chickens. Mendes et al. (1997) and Brake et al. (1998) also reported improved feed conversion ratio with the addition of Arg to broilers' diet. Arginine was reported to exhibit a secretagogue activity by which, it induces the release of pituitary and pancreatic hormones, which in turn improve feed intake, feed conversion ratio, and indirectly protein synthesis (Davila et al., 1987). Arginine is a primary component of proteins, which are only derived from the diet. Hence, a dietary deficiency of Arg will adversely affect protein synthesis and growth (Khajali et al., 2011). The result of the present study corroborated the findings of 
Labadan Jr et al. (2001) who reported that supplemental Arg are needed for improved feed conversion rather than for live weight gain in broilers.

\subsection{Apparent nutrient digestibility}

A linear increase in dry matter, crude protein, ether extract, and crude fibre digestibility values of grower turkeys obtained in the current study with increasing Arg supplementation agreed with Uni and Ferket, (2003) who reported that Arg improved the normal functioning of the digestive system in both mammals, and birds, thereby enhancing improved nutrient utilization. Zhan et al. (2008) also reported that dietary Arg supplementation enhanced gut development and increased intestinal growth, which in turn resulted in positive influence on nutrient absorption and digestion. Improved nutrient

\subsection{Metabolizable energy}

Greater AME values obtained with grower turkeys fed the diets supplemented with Arg when compared with the control group implied improved metabolizable energy values of the diets supplemented with Arg. This could be due to improved physiological functions of digestive system following arg supplementation (Uni and Ferket, 2003). Zhan et al. (2008) earlier reported that dietary Arg supplementation enhanced gut development, which resulted 
in improved intestinal growth with positive effect on nutrient absorption. Greater AME, AMEn, and TME values obtained for grower turkeys as Arg supplementation increased from 0 to $0.5 \mathrm{~g} \mathrm{Arg} / \mathrm{kg}$ when compared with other dietary treatments suggested better dietary energy utilization at $0.50 \mathrm{~g}$ Arg/kg. However, Arg supplementation had no effect on AME, AMEn, TME, and TME values of finisher turkeys in this study.

The differences in response of grower and finisher turkeys in terms of metabolizable energy values following dietary Arg supplementation might be as a result of age differences. Sulistiyanto et al. (1999) reported that utilization of energy-yielding feedstuffs in poultry birds was age dependent. Batal and Parsons (2002) also reported that younger birds showed increased nutrient utilization than older birds. Ruth and Field (2013) reported that during critical periods of development such as growing phase, dietary Arg concentration and availability is of significant importance to the structure, and functioning of the intestine than at maturity.

\subsection{Intestinal morphology}

The linear and quadratic reduction in duodenal and jejunal apical widths of grower turkeys, and quadratic reduction in duodenal apical width of finisher turkeys obtained with increasing Arg supplementation in the present study suggested increased mature enterocytes, signifying increased enzyme activity in the villus brush border (Chen et al., 2011). A linear and quadratic increase in duodenal and ileum villus heights of grower turkeys, ileum villus heights of finisher turkeys, and quadratic increase in the jejunal villus heights of finisher turkeys recorded with increasing Arg supplementation in the present study suggested that Arg promoted increased villus height and consequently increased nutrient absorption. The size and height of villi are important for intestinal function (Yamauchi et al., 1993) as increased 
villi height have been suggested to lead to increase in the intestinal surface area and consequently increased nutrient absorption (Soltan, 2009).

Arginine is involved in the synthesis of polyamines, which in turn are associated with cell division, protein synthesis, intestine development, and tissue growth (Pegg and McCann 1982; Tan et al., 2010). Arginine needs to be hydrolyzed into urea and ornithine by kidney arginase during the synthesis of polyamines (Wu and Morris 1998). Reduction or absence of polyamines has been reported by Ruemmele et al. (1999) to inhibit the proliferation, migration, and apoptosis of intestine cells. As a precursor of polyamines, Arg may be considered a trophic agent in the stimulation of the development of intestinal mucosa, accelerating the mitotic process in the villus-crypt region with a resultant increase in the number, and size of villus cells resulting in increased nutrient uptake (Ruemmele et al., 1999). Liu et al. (2012) also reported that dietary Arg facilitated the uptake of more nutrients from the maternal to the fetus tissue for fetal development. The positive effect of Arg on gut morphology noticed in this study agreed with findings of Zhan et al. (2008) who reported that dietary supplementation with Arg had a positive effect on villus height in the small intestine of early weaned pigs. Foye et al. (2007) reported that Arg when administered in ovo resulted in enhanced intestinal uptake in turkeys. Intestinal villi conformation have been reported to be linked with growth as longer villi were associated with increased body weight gain (Maneewan and Yamauchi, 2004). Higher values of villi heights were observed in chickens that showed increased body weight (Solis De Los Santos et al., 2007).

\section{Conclusion}

Dietary supplementation with Arg from the present study showed a linear improvement in dry matter, crude protein, and ether extract digestibility of grower turkeys. Arginine supplementation improved intestinal morphology as indicated by increased villus 
height in grower and finisher turkeys. Furthermore, dietary supplementation with $0.5 \mathrm{~g}$ Arg/kg improved the feed conversion ratio of finisher turkeys and promoted a quadratic improvement in metabolizable energy values of grower turkeys.

\section{Conflict of interest statement}

There is no conflict of interest with any individual or organization regarding the materials discussed in the manuscript.

\section{Acknowledgement}

The authors are grateful to the College of Animal Science and Livestock Production, and the World Bank Centre of Excellence in Agricultural Development and Sustainable Environment anchored in Federal University of Agriculture (Abeokuta, Nigeria) for sponsoring this project. Equipment subsidy grant from Alexander von Humboldt Foundation (Bonn, Germany) received by O.O. Oluwatosin facilitated this work.

\section{References}

AOAC, 2000. Official method of Analysis of AOAC Int., 17th ed. Assoc. Off. Anal. Chem. Washington, DC., US.

Attia, Y.A., Hassan, R.A., Tag El-Din, A.E., AbouShehema, B.M., 2011. Effect of ascorbic acid or increasing metabolizable energy level with or without supplementation of some essential amino acids on productive and physiological traits of slow growing chicks exposed to chronic heat stress. J. Anim. Physiol. Anim. Nutr. 95, 744-755.

Batal, A. B., Parsons, C. M., 2002. Effects of age on nutrient digestibility in chicks fed different diets. Poult. Sci. 81, 400-407. 
Brake, J., Balnave, D., Dibner, J. J., 1998. Optimum dietary arginine:lysine ratio for broiler chickens is altered during heat stress in association with changes in intestinal uptake and dietary sodium chloride. Br. Poult. Sci. 39, 639-647.

Burt, D.W., 2002. Applications of biotechnology in the poultry industry. World's Poult. Sci. J. 58, 5-13.

Chen, J., Wang, M., Kong, Y., Ma, H., Zou, S., 2011. Comparison of the novel compounds creatine and pyruvate on lipid and protein metabolism in broiler chickens. Anim. $5,1082-1089$

Costa, F. G. P., Rostagno, H. S., Toledo, R.S., Albino, L. F. T., 2001. Arginine/lysine ratio: Effect on performance and carcass quality of 3-wks broilers raised under high temperature. Revta. Bras. Zootec. 30, 2021-2025.

Davila, D. R., Brief, S., Simon, J., Hammer, R.E., Brinster, R. L., Kelley, K. W., 1987. Role of growth hormone in regulating $\mathrm{T}$ dependent immune events in aged, nude, and transgenic rodents. J. Neurosci. Res. 18, 108-116.

European Commission, 1998. European Commission Directive 98/64/EC of 3 September 1998. Establishing community methods of analysis for the determination of amino acids, crude oils and fats, and olaquindox in feedingstuffs and amending Directive 71/393/ EEC (Text with EEA relevance). Off. J. Eur. Communities L 257:16-23.

Foye, O. T., Ferket, P. R., Uni, Z., 2007.The effects of in ovo feeding arginine, $\beta$-hydroxy- $\beta$ methyl-butyrate, and protein on jejunal digestive and absorptive activity in embryonic and neonatal turkey poults. Poult. Sci. 86, 2343-2349.

Hampson, D. J., 1986. Alterations in piglet small intestinal structure at weaning. Res. Vet. Sci. 40, 32-40. 
Khajali, F., Tahmasebi, M., Hassanpour, H., Akbari, M.R., Qujeq, D., Wideman, R. F., 2011. Effects of supplementation of canola meal-based diets with arginine on performance, plasma nitric oxide and carcass characteristics of broiler chickens grown at high altitude. Poult. Sci. 90, 2287-2294.

Kidd, M. T., Peebles, E. D., Whitmarsh, S. K., Yeatman, J. B., Wideman Jr, R. F., 2001. Growth and immunity of broiler chicks as affected by dietary arginine. Poult. Sci. $80,1535-1542$.

Kim, S. W., Wu, G., 2004. Dietary arginine supplementation enhances the growth of milk-fed young pigs. J. Nutr. 134, 625-630.

Kim, S. W., McPherson, R. L., Wu, G. 2004. Dietary arginine supplementation enhances the growth of milk-fed young pigs. J. Nutr. 134, 625-630.

Kim, S. W., Mateo, R. D., Yin, Y. L., Wu, G. Y., 2007. Functional amino acids and fatty acids for enhancing production performance of sows and piglets. AsianAustralas. J. Anim. Sci. 20, 295-306.

Kwak, H., Austic, R. E., Dietert, R. R., 1999. Influence of dietary arginine concentration on lymphoid organ growth in chickens. Poult. Sci. 78, 1536-1541.

Labadan Jr, M. C., Hsu, K. N., Austic, R. E., 2001. Lysine and arginine requirements of broiler chickens at two to three weeks intervals to eight weeks of age. Poult. Sci. 80, 599-606.

Lewis, S., 1996. Avian Biochemistry and Molecular Biology. Cambridge University Press, New Jersey, New York City, USA.

Lin, H., Jiao, H.C., Buyse, J., Decuypere, E., 2006. Strategies for preventing heat stress in poultry. World's Poult. Sci. J. 62, 71-85. 
Liu, X., Wu, X., Yin, Y., Liu, Y., Geng, M., Yang, H., Wu, G., 2012. Effects of dietary Larginine or N-carbamylglutamate supplementation during late gestation of sows on the miR-15b/16, miR-221/222,VEGFA and eNOS expression in umbilicalvein. Amino Acids 42, 2111-2119.

Maneewan, B., Yamauchi, K., 2004. Intestinal villus recovery in chickens re-fed semi purified protein, fat, or fibre-free pellet diets. Br. Poult. Sci. 45, 163-170.

Mendes, A. A., Watkins, S. E., England, J. A., 1997. Influence of dietary lysine levels and arginine:lysine ratios on performance of broilers exposed to heat or cold stress during the period of three to six weeks of age. Poult. Sci. 76, 472-481.

Mujahid, A., Pumford, N., Bottje, W., Akiba, Y., Toyomizu, M., 2007. Mitochondrial oxidative damage in chicken skeletal muscle induced by acute heat stress. J. Poult. Sci. 44, 439-445.

Munir, K., Muneer, M.A., Masaoud, E., Tiwari, A., Mahmud, A., Chaudhry, R. M., 2009. Dietary arginine stimulates humoral and cell-mediated immunity in chickens vaccinated and challenged against hydropericardium syndrome virus. Poult. Sci. $88,1629-1638$.

Newsholme, P., Brennnan, L., Rubi, B., Maechler, P., 2005. New insights into amino acid metabolism, beta-cell function and diabetes. Clin. Sci. 108, 185-194.

NRC, 1994. Nutrient Requirements of Poultry, 9th ed. Natl Acad. Press, Washington, D.C., US.

Pegg, A. E., McCann, P. P., 1982. Polyamine metabolism and function. Am. J. Physiol. Cell Physiol. 243, 212-221. 
Ren, W., Chen, S., Yin, J., Duan, J., Li, T., Liu, G., Feng, Z., Tan, B., Yin, Y., Wu, G., 2014a. Dietary arginine supplementation of mice alters the microbial population and activates intestinal innate immunity. J. Nutr. 166, 988-995.

Ren, W., Yin, J., Wu, M., Liu, G., Yang, G., Xion, Y., Su, D., Wu, L., Li, T., Chen, S., Duan, J., Yin, Y., Wu, G., 2014b. Serum amino acids profile and the beneficial effects of L-arginine or L-glutamine supplementation in Dextran Sulfate Sodium Colitis. PLoS One 9, e88335.

Ruemmele, F. M., Ruemmele, C., Levy, E., Seidman, E., 1999. Molecular mechanism regulating intestinal epithelial cell turn over by nutrients. Gastroenterol. Clin. Biol. $23,47-55$.

Ruth, R. M., Field, C. J., 2013. The immune modifying effects of amino acids on gutassociated lymphoid tissue. J. Anim. Sci. Biotech. 4, 27-32.

SAS, 1999. SAS/STAT User's Guide. SAS Inst. Inc., Cary, NC, US.

Sibbald, I. R., 1989. Metabolizable energy evaluation of poultry diets, in: Cole, D.J.A., Haresign, W. (Eds), Recent Developments in Poultry Nutrition. Ancho Press Ltd. Tiptree, Essex, England, UK, pp. 12-26.

Solis De Los Santos, F., Donoghue, A. M., Farnell, M. B., Huff, G. R., Huff, W. E., Donoghue, D. J., 2007. Gastrointestinal maturation is accelerated in turkey poults supplemented with a mannan-oligosaccharide yeast extract. Poult. Sci. 86, 921930.

Soltan, M. A. 2009. Influence of dietary glutamine supplementation on growth performance, small intestinal morphology, immune response and some blood parameters of broiler chickens. Int. J. Poult. Sci. 8, 60-68. 
Stevens, B., Godfrey, M., Kaminski, T., Braith, R., 2000. High intensity dynamic human muscle performance enhanced by a metabolic intervention. Med. Sci. Sports Exercise, 32, 2102-2104.

Sulistiyanto, B., Akiba, Y., Sato, K., 1999. Energy utilisation of carbohydrate, fat and protein sources in newly hatched broiler chicks. Br. Poult. Sci. 40, 653-659.

Takahashi, K., Orihashi, M., Yukio, A., 1999. Dietary L- arginine level alters plasma nitric oxide and apha-1 acid glycoprotein concentrations, and splenocyte proliferation in male broiler chickens following Escherichia coli lipopolysaccharide injection. Comp. Biochem. Physiol. Toxicol. Pharmacol. 124, 309-314.

Tamir, H., Ratner, S., 1963. Enzymes of arginine metabolism in chicks. Arch. Physiol. Biochem. 102, 249-269.

Tan, B., Yin, Y., Liu, Z., Li, X., Xu, H., Kong, X., Huang, R., Tang, W., Shinzato, I., Smith, S., Wu, G., 2009. Dietary L-arginine supplementation increases muscle gain and reduces body fat mass in growing-finishing pigs. Amino Acids. 37, 169-175.

Tan, B., Yin, Y., Kong, X., Li, P., Li, X., Gao, H., Li, X., Huang, R., Wu, G., 2010. LArginine stimulates proliferation and prevents endotoxin-induced death of intestinal cells. Amino Acids 38, 227-235.

Uni, Z., Ferket, P., 2003. Enhancement of development of oviparous species by in ovo feeding. U.S. Regular Patent US 6,592,878 B2, Washington, DC., US.

Veldkamp, T., Kwakkel, R.P., Ferket, P.R., Simons, P.C.M., Noordhuizen, J.P.T.M., Pijpers, A., 2000. Effects of ambient temperature, arginine to lysine ratio, and electrolyte balance on performance, carcass, and blood parameters in commercial male turkeys. Poult. Sci. 79, 1608-1616.

Vieira, S. L., Berres, J., 2007. Effects of limiting amino acids in fattening poultry birds. XX 
479

480

481

482

483

484

485

486

487

488

489

490

491

492

493

494

495 496

497

498

499

500

501

Wu, G., Morris Jr, S. M., 1998. Arginine metabolism: Nitric oxide and beyond. Biochem. J. 336, 1-17.

Yamauchi, K., Nakamura, E., Isshiki, Y., 1993. Development of the intestinal villi associated with the increased epithelial cell mitosis in chickens. Anim. Feed Sci. Technol. $64,340-350$

Yao, K., Guan, S., Li, T., Huang, R., Wu, G., Ruan, Z., 2011. Dietary L- arginine supplementation enhances intestinal development and expression of vascular endothelial growth factor in weanling piglets. Br. J. Nutr. 105, 703-709.

Yin, J., Ren, W., Duan, J., Wu, L., Chen, S., Li, T., Yin, Y., Wu, G., Yin, J., Ren, W., Duan, J., Wu, L., Chen, S., Li, T., Yin, Y., Wu, G. 2014. Dietary arginine supplementation enhances intestinal expression of SLC7A7 and SLC7A1 and ameliorates growth depression in mycotoxin-challenged pigs. Amino Acids 46, $883-892$.

Zhan, Z., Ou, D., Piao, X., Kim, S. W., Liu, Y., Wang, J., 2008. Dietary arginine supplementation affects microvascular development in the small intestine of early-weaned Pigs. J. Nutr. 138, 1304-1309. 
504 Composition of basal diet for grower (d 56 to 84), and finisher (d 84 to 112) turkeys ${ }^{\mathrm{a}}$

\begin{tabular}{lll}
\hline Item & Grower & Finisher \\
\hline Ingredient $(\mathrm{g} / \mathrm{kg})$ & & \\
Maize & 575 & 622 \\
Fish meal $(720 \mathrm{~g} / \mathrm{kg})$ & 89 & 46 \\
Soybean meal & 264 & 240 \\
Soybean oil & - & 2 \\
Wheat offal & 47 & 65 \\
Bone meal & 6 & 6 \\
Limestone & 8 & 8 \\
Vitamin/mineral premix & 5 & 5 \\
L-Lys & 1 & 1 \\
DL-Met & 2 & 2 \\
Salt & 3 & 3 \\
Total & 1,000 & 1,000
\end{tabular}

Calculated composition

$\begin{array}{lll}\mathrm{Ca}(\mathrm{g} / \mathrm{kg}) & 10.5 & 9.5\end{array}$

$\mathrm{P}(\mathrm{g} / \mathrm{kg})$

$6.5 \quad 5.4$

Metabolizable energy

$3,196 \quad 3,275$

$(\mathrm{kcal} / \mathrm{kg})$

Determined composition (g/kg DM basis)

Crude protein

$230.3 \quad 195.5$

Crude fibre

$33.2 \quad 39.0$

Ether extract

$32.1 \quad 30.7$

Indispensable amino acids

$\begin{array}{lll}\text { Arg } & 16.3 & 14.3 \\ \text { His } & 6.6 & 5.9 \\ \text { Ile } & 11.0 & 9.3 \\ \text { Leu } & 21.6 & 20.0 \\ \text { Lys } & 14.3 & 11.3 \\ \text { Met } & 5.5 & 4.6 \\ \text { Phe } & 11.7 & 10.5 \\ \text { Thr } & 11.5 & 8.1 \\ \text { Val } & 12.4 & 10.3\end{array}$

Dispensable amino acids

$\begin{array}{lll}\text { Asp } & 24.8 & 21.4 \\ \text { Cys } & 36.0 & 33.0 \\ \text { Glu } & 43.4 & 39.9 \\ \text { Gly } & 11.2 & 9.4 \\ \text { Ala } & 13.7 & 11.9 \\ \text { Pro } & 14.8 & 14.0 \\ \text { Ser } & 11.5 & 10.3 \\ \text { Tyr } & 5.2 & 4.8\end{array}$


pantothenate, $0.07 \mathrm{~g}$ choline chloride; $12 \mathrm{mg}$ antioxidant (butylhydroxytoluene); $0.23 \mathrm{~g} \mathrm{Ca}$; 
Table 2

512 The growth performance of grower (d 56 to 84), and finisher (d 84 to 112) turkeys fed diet 513 supplemented with $\mathrm{Arg}^{\mathrm{a}}$

\begin{tabular}{|c|c|c|c|c|c|c|}
\hline \multirow[t]{2}{*}{ Item } & \multicolumn{3}{|c|}{$\operatorname{Arg}(\mathrm{g} / \mathrm{kg})$} & \multirow{2}{*}{$\begin{array}{l}\text { Pooled } \\
\text { SEM }\end{array}$} & \multicolumn{2}{|c|}{$P$-value } \\
\hline & 0 & 0.5 & 1.0 & & Linear & Quadratic \\
\hline \multicolumn{7}{|l|}{$\begin{array}{l}\text { Body weight } \\
\text { (g/turkey) }\end{array}$} \\
\hline d 56 & 2,627 & 2,572 & 2,743 & 8 & 0.113 & 0.164 \\
\hline d 84 & 5,893 & 5,730 & 6,025 & 11 & 0.419 & 0.115 \\
\hline d 112 & 9,030 & 8,772 & 9,500 & 201 & 0.184 & 0.039 \\
\hline \multicolumn{7}{|c|}{$\begin{array}{l}\text { Average daily feed } \\
\text { intake (g/turkey) }\end{array}$} \\
\hline d 56 to 84 & 292 & 292 & 299 & 4 & 0.661 & 0.803 \\
\hline d 84 to 112 & 457 & 412 & 617 & 55 & 0.009 & $<0.001$ \\
\hline d 56 to 112 & 375 & 352 & 458 & 36 & 0.022 & 0.017 \\
\hline \multicolumn{7}{|c|}{$\begin{array}{l}\text { Average daily weight } \\
\text { gain (g/turkey) }\end{array}$} \\
\hline d 56 to 84 & 117 & 113 & 117 & 6 & 0.654 & 0.688 \\
\hline d 84 to 112 & 112 & 109 & 124 & 8 & 0.304 & 0.385 \\
\hline d 56 to 112 & 114 & 111 & 121 & 5 & 0.099 & 0.075 \\
\hline \multicolumn{7}{|c|}{ Feed conversion ratio } \\
\hline d 56 to 84 & 2.51 & 2.59 & 2.55 & 0.02 & 0.628 & 0.744 \\
\hline d 84 to 112 & 4.08 & 3.79 & 4.97 & 0.23 & 0.062 & 0.028 \\
\hline d 56 to 112 & 3.28 & 3.18 & 3.79 & 0.90 & 0.015 & 0.075 \\
\hline
\end{tabular}


516 Table 3

517 Dry matter and nutrient digestibility (\%) of grower (at d 84), and finisher (at d 112) fed diet 518 supplemented with $\mathrm{Arg}^{\mathrm{a}}$

\begin{tabular}{|c|c|c|c|c|c|c|}
\hline \multirow[t]{2}{*}{ Item } & \multicolumn{3}{|c|}{$\operatorname{Arg}(\mathrm{g} / \mathrm{kg})$} & \multirow{2}{*}{$\begin{array}{l}\text { Pooled } \\
\text { SEM }\end{array}$} & \multicolumn{2}{|l|}{$P$-value } \\
\hline & 0 & 0.5 & 1.0 & & Linear & Quadratic \\
\hline \multicolumn{7}{|l|}{ d 84} \\
\hline Dry matter & 78.37 & 83.55 & 86.81 & 4.05 & $<0.001$ & 0.507 \\
\hline Crude protein & 59.28 & 69.30 & 70.66 & 2.66 & $<0.001$ & 0.929 \\
\hline Ether extract & 72.78 & 74.86 & 75.17 & 2.39 & $<0.001$ & 0.697 \\
\hline Crude fibre & 56.26 & 62.19 & 69.23 & 2.26 & $<0.001$ & 0.716 \\
\hline Ash & 52.04 & 51.40 & 64.99 & 2.60 & $<0.001$ & 0.391 \\
\hline \multicolumn{7}{|l|}{ d 112} \\
\hline Dry matter & 88.24 & 87.63 & 84.09 & 2.72 & 0.014 & 0.030 \\
\hline Crude protein & 69.65 & 71.37 & 70.34 & 0.96 & 0.255 & 0.275 \\
\hline Ether extract & 61.57 & 59.57 & 61.96 & 1.44 & 0.730 & 0.069 \\
\hline Crude fibre & 61.01 & 63.97 & 68.56 & 0.65 & 0.059 & 0.173 \\
\hline Ash & 62.12 & 69.76 & 78.25 & 1.98 & $<0.001$ & $<0.001$ \\
\hline
\end{tabular}


522 Metabolizable energy values (MJ/Kg) of grower (at d 84), and finisher (at d 112) turkeys fed 523 diet supplemented with $\mathrm{Arg}^{\mathrm{a}}$

\begin{tabular}{llllllll}
\hline & \multicolumn{2}{l}{$\operatorname{Arg}(\mathrm{g} / \mathrm{kg})$} & Pooled SEM & \multicolumn{2}{c}{$P$-value } \\
\cline { 2 - 3 } Item & 0 & 0.5 & 1.0 & & & Linear & Quadratic \\
\hline d 84 & 13.74 & 14.91 & 14.25 & 1.69 & 0.054 & $<0.001$ \\
AME & 13.47 & 14.17 & 13.14 & 2.01 & 0.139 & $<0.001$ \\
AMEn & 15.95 & 16.68 & 15.75 & 2.72 & 0.417 & $<0.001$ \\
TME & 12.57 & 13.08 & 12.14 & 2.50 & 0.201 & 0.021 \\
TMEn & & & & & & \\
d 112 & 14.75 & 14.51 & 14.45 & 0.08 & 0.124 & 0.278 \\
AME & 13.75 & 13.45 & 13.54 & 0.07 & 0.216 & 0.182 \\
AMEn & 14.71 & 14.31 & 14.51 & 0.08 & 0.337 & 0.134 \\
TME & 14.87 & 14.69 & 14.76 & 0.12 & 0.589 & 0.475 \\
TMEn & 6
\end{tabular}

$524{ }^{a}$ Based on 6 pens/treatment, SEM = standard error of the mean, AME = apparent

525 metabolizable energy, AMEn = apparent metabolizable energy corrected for nitrogen, TME = 526 true metabolizable energy, and TMEn = true metabolizable energy corrected for nitrogen. 


\section{Table 5}

529 Effect of Arg supplementation on intestinal morphology $(\mu \mathrm{m})$ of grower (at d 84) turkeys ${ }^{\mathrm{a}}$

\begin{tabular}{|c|c|c|c|c|c|c|}
\hline \multirow[t]{2}{*}{ Item } & \multicolumn{3}{|c|}{$\operatorname{Arg}(\mathrm{g} / \mathrm{kg})$} & \multirow{2}{*}{$\begin{array}{l}\text { Pooled } \\
\text { SEM }\end{array}$} & \multicolumn{2}{|l|}{$P$-value } \\
\hline & 0 & 0.5 & 1.0 & & Linear & Quadratic \\
\hline \multicolumn{7}{|l|}{ Duodenum } \\
\hline Villus height & 1,070 & 1,350 & 1,463 & 115 & $<0.001$ & $<0.001$ \\
\hline Apical width & 92.7 & 57.7 & 54.0 & 8.5 & 0.003 & $<0.001$ \\
\hline Basal width & 170 & 130 & 150 & 23 & 0.286 & 0.047 \\
\hline Crypt depth & 475.0 & 437.7 & 587.7 & 29.9 & 0.043 & $<0.001$ \\
\hline \multicolumn{7}{|l|}{ Jejunum } \\
\hline Villus height & 1,675 & 2,055 & 1,418 & 124 & 0.193 & $<0.001$ \\
\hline Apical width & 119.0 & 52.7 & 47.7 & 11.6 & $<0.001$ & $<0.001$ \\
\hline Basal width & 238 & 248 & 180 & 21 & 0.095 & 0.087 \\
\hline Crypt depth & 468 & 495 & 385 & 28 & 0.055 & $<0.001$ \\
\hline \multicolumn{7}{|l|}{ Ileum } \\
\hline Villus height & 370 & 475 & 1,013 & 109 & $<0.001$ & $<0.001$ \\
\hline Apical width & 98 & 80 & 80 & 9 & 0.010 & 0.004 \\
\hline Basal width & 165 & 140 & 118 & 16 & 0.004 & 0.021 \\
\hline Crypt depth & 1,575 & 1,475 & 775 & 108 & $<0.001$ & $<0.001$ \\
\hline
\end{tabular}


533 Effect of Arg supplementation on intestinal morphology $(\mu \mathrm{m})$ of finisher (at d 112) turkeys ${ }^{\mathrm{a}}$

\begin{tabular}{|c|c|c|c|c|c|c|}
\hline \multirow[t]{2}{*}{ Item } & \multicolumn{3}{|c|}{$\operatorname{Arg}(\mathrm{g} / \mathrm{kg})$} & \multirow{2}{*}{$\begin{array}{l}\text { Pooled } \\
\text { SEM }\end{array}$} & \multicolumn{2}{|c|}{$P$-value } \\
\hline & 0 & 0.5 & 1.0 & & Linear & Quadratic \\
\hline \multicolumn{7}{|l|}{ Duodenum } \\
\hline Villus height & 1,530 & 1,550 & 1,540 & 32 & 0.075 & 0.099 \\
\hline Apical width & 152.4 & 125.5 & 120.5 & 21.2 & 0.062 & 0.033 \\
\hline Basal width & 255 & 253 & 250 & 6 & 0.189 & 0.077 \\
\hline Crypt depth & 505 & 502 & 501 & 11 & 0.095 & 0.175 \\
\hline \multicolumn{7}{|l|}{ Jejunum } \\
\hline Villus height & 1,850 & 2,001 & 2,200 & 196 & 0.065 & 0.042 \\
\hline Apical width & 149.2 & 152.4 & 150.5 & 8.3 & 0.099 & 0.078 \\
\hline Basal width & 286 & 289 & 290 & 9 & 0.095 & 0.087 \\
\hline Crypt depth & 527 & 531 & 523 & 21 & 0.094 & 0.095 \\
\hline \multicolumn{7}{|l|}{ Ileum } \\
\hline Villus height & 450.6 & 496.6 & 500.8 & 99.2 & 0.022 & 0.042 \\
\hline Apical width & 122.2 & 125.1 & 120.5 & 6.2 & 0.115 & 0.155 \\
\hline Basal width & 220 & 216 & 222 & 9 & 0.099 & 0.091 \\
\hline Crypt depth & 1,599 & 1,599 & 1,598 & 27 & 0.074 & 0.065 \\
\hline
\end{tabular}

